\title{
Occurrence of fluoride in ground waters of Saudi Arabia
}

\author{
Abdulrahman I. Alabdulaaly • Abdullah I. Al-Zarah • \\ Mujahid A. Khan
}

Received: 4 September 2012/Accepted: 20 May 2013/Published online: 14 June 2013

(C) The Author(s) 2013. This article is published with open access at Springerlink.com

\begin{abstract}
The presence of elevated levels of fluoride in groundwater is considered a global problem. Fluoride in water derives mainly from dissolution of natural minerals in the rocks and soils with which water interacts. The most common fluorine-bearing minerals are fluorite, apatite and micas. Anthropogenic sources of fluoride include agricultural fertilizers and combustion of coal. In the present research, a survey of wells $(n=1,060)$ was undertaken in all the 13 regions of the Kingdom of Saudi Arabia to assess the contained fluoride $(\mathrm{F})$ levels. The results indicated variation in fluoride levels from 0.10 to $5.4 \mathrm{mg} / \mathrm{L}$ as $\mathrm{F}$ throughout the kingdom. The average fluoride levels in milligrams per liter as $\mathrm{F}$ were as follows in descending order: 1.80 (Hadwood Shamalyah), 1.37 (Hail), 1.33 (Eastern Province), 1.16 (Al Jouf), 1.11 (Qassim), 1.01 (Riyadh), 0.90 (Madina Al Munnawara), 0.81 (Tabouk), 0.74 (Makkah Al- Mukaramma), 0.73 (Jizan), 0.66 (Asir), 0.64 (Najran), and 0.60 (Al Baha). The results indicated that fluoride levels exceeded the USEPA maximum contaminant limits for drinking water $(4 \mathrm{mg} / \mathrm{L})$ in several wells $(n=7)$ in different regions of the kingdom and that $13.96 \%$ of the wells exceeded the World Health Organization recommended levels $(1.5 \mathrm{mg} / \mathrm{L})$. The results were also compared with the secondary USEPA contaminant standards of $2.0 \mathrm{mg} / \mathrm{L}$ for fluorides.
\end{abstract}

Keywords Fluoride - Ground water - Saudi Arabia . Occurrence $\cdot$ Health effects

A. I. Alabdulaaly $(\bowtie) \cdot$ A. I. Al-Zarah · M. A. Khan

King Abdulaziz City for Science and Technology,

P.O. Box 6086, Riyadh 11442, Saudi Arabia

e-mail: abdulaly@kacst.edu.sa

\section{Introduction}

Fluoride is an essential element for both humans and animals, and its behavior in drinking water is vital. Optimum content $(1.5 \mathrm{mg} / \mathrm{L})$ of $\mathrm{F}$ in water is essential for growth of bones and formation of dental enamels. Higher contents $(>1.5 \mathrm{mg} / \mathrm{L})$ pose a threat to human health, and can cause severe health problems such as dental and skeletal fluorosis, particularly in arid and semi-arid regions of the world. For example, F problems occur in some regions of India, China, the Korean Peninsula, East and North Africa, the United Kingdom, and the Western United States (Ayoob and Gupta 2006; Chae et al. 2007; Harrison 2005; Jacks et al. 2005; Kim and Jeong 2005; Reddy et al. 2010; Xiong et al. 2007; Zhu et al. 2007). Conversely, water fluoridation is necessary in Australia, New Zealand, Canada, and most South American countries, due to lack of natural fluoride. However, Scandinavian countries where dental awareness is very high, use alternative sources, such as fluoride-rich toothpaste (Lennon et al. 2004). Fluorine is available in soils and waters due to the weathering of fluoride-bearing minerals predominantly of igneous origin (Breiter and Kronz 2004; Breiter et al. 2006; Lukkari and Holtz 2007; Reddy et al. 2010; Totsche et al. 2000; Zhu et al. 2007). Apatite $\left[\mathrm{Ca}_{5}\left(\mathrm{PO}_{4}\right)_{3} \mathrm{~F}\right]$ and fluorite $\left[\mathrm{CaF}_{2}\right]$ are the most common fluoride-bearing minerals. However, zircon $\left[\mathrm{ZrSiO}_{4}\right]$ is also a possible source for fluoride in water or soil, as igneous zircons contain fluorine complexes (Farges 1996; Keppler 1993). Biotite $\left[\mathrm{K}(\mathrm{Mg}, \mathrm{Fe})_{3} \mathrm{AlSi}_{3} \mathrm{O}_{10}\right.$ $\left.(\mathrm{F}, \mathrm{OH})_{2}\right]$, hornblende $\left[(\mathrm{Ca}, \mathrm{Na})_{2-3}(\mathrm{Mg}, \mathrm{Fe}, \mathrm{Al})_{5}(\mathrm{Al}, \mathrm{Si})_{8} \mathrm{O}_{22}\right.$ $\left.(\mathrm{OH}, \mathrm{F})_{2}\right]$ and soils that consist mainly of clay minerals such as vermiculite $\left[(\mathrm{MgFe}, \mathrm{Al})_{3}(\mathrm{Al}, \mathrm{Si})_{4} \mathrm{O}_{10}(\mathrm{OH})\right]$, kaolinite $\left[\mathrm{Al}_{2} \mathrm{Si}_{2} \mathrm{O}_{5}(\mathrm{OH})_{4}\right]$ and montmorillonite $\left[(\mathrm{Na}, \mathrm{Ca})_{0.33}\right.$ $\left.(\mathrm{Al}, \mathrm{Mg})_{2}\left(\mathrm{Si}_{4} \mathrm{O}_{10}\right)(\mathrm{OH})_{2} \cdot \mathrm{nH}_{2} \mathrm{O}\right]$ are also major sources of fluoride (Wodeyar and Sreenivasan 1996; Zhu et al. 2007). 
The problems associated with high fluoride content in groundwater in the dry zone of Sri Lanka are well known (Lennon et al. 2004). It has been found that both shallow and deep groundwater exceeded the World Health Organization (WHO) recommended levels in drinking water ( $>1.5 \mathrm{mg} / \mathrm{L})$. Agrawal (1997) reports that in Sri Lanka, fluoride has a strong geographical control linked to climatic conditions, with high fluoride waters being restricted to the dry zone on the eastern side of the island. In some parts, wells have fluoride content $>10 \mathrm{mg} / \mathrm{L}$.

Generally, most groundwater sources have higher fluoride concentrations than surface water. As groundwater percolates through the weathered rock in the aquifers, it dissolves fluoride-bearing minerals thus releasing fluoride into solution (Falvey 1999). Because of the large number of variables, the fluoride concentrations in groundwater can range from well under $1 \mathrm{mg} / \mathrm{L}$ to more than $35 \mathrm{mg} / \mathrm{L}$ (WHO 1994). Studies have shown that the problem of high fluoride content in groundwater is very acute in mainland Tanzania (Mjengera and Mkongo 2002). The high fluoride content is attributed to some geological processes such as volcanic activities, thermal springs and the presence of minerals such as fluorite and apatite in rocks. For example, borehole water in South Sanya corridor was found to contain up to $96 \mathrm{mg} / \mathrm{L}$ fluoride. An area west of Ngorongoro Crater had fluoride content in spring water between 40 and $140 \mathrm{mg} / \mathrm{L}$ (Mjengera and Mkongo 2002). High fluoride groundwater has also been reported in Mexico (Alarcon-Herrera et al. 2001). In Guadiana Valley, drinking water supply is obtained from underground wells and is characterised by a high content of fluoride. Hurtado et al. (2000) reported that in Los Altos de Jalisco, situated in central Mexico, communities use water with a fluoride concentration of up to $12.97 \mathrm{mg} / \mathrm{L}$. In northern China, high fluoride groundwater with fluoride concentration of up to $6.20 \mathrm{mg} / \mathrm{L}$ occurs in the Taiyuan basin (Qinghai et al. 2007). The study showed that high fluoride groundwater zones are mainly located in the discharge areas, especially in places where shallow groundwater occurs (the groundwater depth is $<4 \mathrm{~m}$ ). Modeling results indicated that in the recharge and flow through area of the northern Taiyuan basin, interactions between groundwater and fluoride-rich minerals are the major factor for the increase of fluoride concentrations, whereas in the discharge area of the northern basin, evaporation as well as the mixing of karst water has greater contribution to the fluoride enrichment in groundwater. A study was carried out on fluoride distribution in Ethiopia (Redda Tekle-Haimanot et al. 2006). Of the total 1,438 water samples tested, $24.2 \%$ had fluoride concentration above the $1.5 \mathrm{mg} / \mathrm{L}$ guideline concentration recommended by WHO. The highest fluoride levels were recorded in the Rift Valley, where $41.2 \%$ of all samples exceeded the $1.5 \mathrm{mg} / \mathrm{L}$ level. Only $1.0 \%$ of the samples from the central and northwestern highlands and $10.0 \%$ in the southeastern highlands exceeded $1.5 \mathrm{mg} / \mathrm{L}$. Larger proportions of deep wells $(50.0 \%)$ and hot springs $(90.0 \%)$ than shallow wells $(27.2 \%)$ and cold springs (12.6\%) exceeded the $1.5 \mathrm{mg} / \mathrm{L}$ level. The highest fluoride concentrations were recorded for Rift Valley lakes Shala $(264.0 \mathrm{mg} / \mathrm{L})$ and Abijata $(202.4 \mathrm{mg} / \mathrm{L})$ and the lowest in Lake Tana, rivers, wells and springs in the highlands. Groundwater is the most widely used drinking water source in the upper regions of Ghana. In most parts of the upper regions, groundwater fluoride ranges from 0.11 to $4.60 \mathrm{mg} /$ L (Apambire et al. 1998). About $28 \%$ of the wells in the region have drinking water with fluoride concentration above the WHO recommended level. Apambire et al. (1998) recommended using geochemical health risk maps showing fluoride levels in groundwater, so that health and water officials should have information on fluoride occurrence in groundwater. Mgalela (1997) reported high fluoride groundwater in some parts of Gokwe district in Zimbabwe. He recommended a thorough mapping of all wells of this area to delineate those with fluoride content above optimum level. In Malawi, the Ministry of Health and Population conducted a survey in Machinga on occurrence of high fluoride groundwater (MOH 1996; Sibale et al. 1998). A few boreholes were sampled for fluoride determination in Machinga where fluoride content in water sources was as high as $8.6 \mathrm{mg} / \mathrm{L}$ (Sibale et al. 1998). In Nkhota Kota district, an area lying in the rift valley, water from hot springs has a fluoride content of up to about $17 \mathrm{mg} / \mathrm{L}$ and Chikwidzi spring is about $8 \mathrm{mg} /$ L (Chapusa and Harrison 1975). Data on fluoride occurrence in groundwater in most parts of Malawi are not available because very little research work has been carried out on the occurrence of fluoride in drinking water supplies.

\section{Beneficial and toxic effects of fluoride}

Fluoride is widely used in dental preparations to combat dental caries, particularly in areas of high sugar intake. These can be in the form of tablets, mouthwashes, toothpaste, varnishes or gels for local application. In some countries, fluoride may also be added to table salt or drinking water to provide protection against dental caries. The amounts added to drinking-water are such that final concentrations are usually between 0.5 and $1 \mathrm{mg} / \mathrm{L}$ (WHO 2011)

Elevated fluoride intakes can have more serious effects on skeletal tissues. Skeletal fluorosis (with adverse changes in bone structure) may be observed when drinking water contains 3-6 mg of fluoride per liter, particularly with high water consumption. Crippling skeletal fluorosis usually 


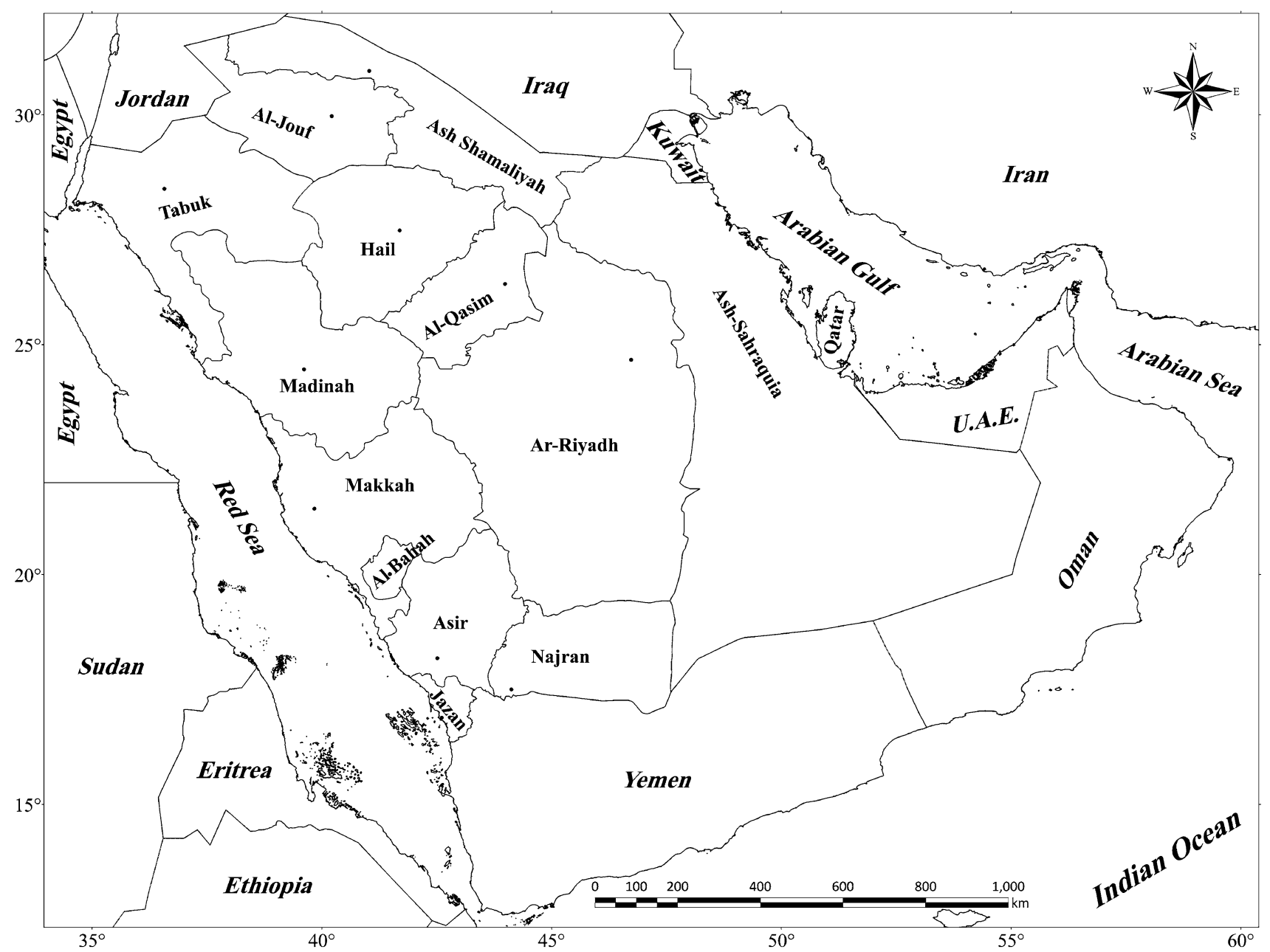

Fig. 1 Map shows different regions in the Kingdom of Saudi Arabia where well water sampling was undertaken

develops only where drinking-water contains over $10 \mathrm{mg}$ of fluoride per liter (WHO 2011).

Exposure to excessive consumption of fluoride over a lifetime may lead to increased likelihood of bone fractures in adults, and may result in effects on bone leading to pain and tenderness. Children aged 8 years and younger exposed to excessive amounts of fluoride have an increased chance of developing pits in the tooth enamel, along with a range of cosmetic effects to teeth (USEPA 2012).

\section{MCL for fluoride concentrations}

USEPA has set a maximum contaminant level (MCL) and also maximum contaminant goal limit (MCLG) of $4 \mathrm{mg} / \mathrm{L}$ for fluoride concentration in the drinking water. However, the secondary US EPA contaminant limit for fluoride is $2.0 \mathrm{mg} / \mathrm{L}$ (USEPA 2012). WHO has recommended a guideline limit of $1.5 \mathrm{mg} / \mathrm{L}$ of fluoride in drinking waters (WHO 2011).

\section{Materials and methods}

Study area

Groundwater samples were collected from wells $(n=1,060)$ located in all 13 regions of Saudi Arabia (Fig. 1). The location of the wells was recorded using Global positioning system. The region wise breakup of sampled wells is shown in Table 1. The sampled wells were a mix of government and private property. Many of the sampled wells were the main source of drinking water for the local population.

\section{Collection of samples}

Groundwater samples were collected in 1-L plastic bottles, which were previously thoroughly washed with tap water and rinsed with distilled water. Samples were stored in ice at the sampling locations and were refrigerated upon arrival in the laboratory until analyzed. Sampling protocol was 
Table 1 Number of Sampled wells in different regions of the Kingdom

\begin{tabular}{lc}
\hline Regions & No. of sampled wells \\
\hline Eastern province & 201 \\
Riyadh & 200 \\
Qassim & 108 \\
Asir & 87 \\
Makkah Al-Mukaramma & 85 \\
Madina Al-Munnawara & 71 \\
Al Baha & 61 \\
Jizan & 57 \\
Hail & 43 \\
Najran & 41 \\
Hadwood Shamalyah & 41 \\
Al Jouf & 34 \\
Tabouk & 31 \\
Total Samples & 1,060 \\
\hline
\end{tabular}

designed in such a way that samples collected in one sampling schedule were analyzed in the shortest possible time.

Analysis of water samples for the determination of fluoride concentration

Water samples were analyzed according to the standard methods (APHA 1999). Water samples were analyzed for fluoride using ion chromatography (Dionex Ion Chromatograph model DX 500). The ion chromatograph was equipped with Dionex Ion Pac AS 14 analytical column with AG 14 guard column. The flow rate of the eluent (4.5 mM sodium carbonate/1.4 mM sodium bicarbonate) in the equipment was kept at $1.4 \mathrm{~mL} / \mathrm{min}$. The injection volume was $10 \mu \mathrm{L}$. The system was calibrated with certified anion standards from Dionex.

Quality assurance and quality control program

To assess the precision and accuracy of results, replicate analysis of blank, standard, and samples was carried out. The relative standard deviations were determined to find the precision of the analysis. Recovery results were calculated for the determination of accuracy. Experiments were repeated till an accuracy of 95-105\% and precision of $\pm 5 \%$ were obtained. Certified standards from Dionex were used for the calibration of the instrument. One standard with one set of sample was analyzed routinely.

Results and discussion

The minimum, maximum, and average fluoride concentrations in the different regions have been presented in
Table 2 and Fig. 2. Table 2 also shows the number of wells exceeding the maximum contaminant fluoride levels. The minimum and maximum fluoride concentrations detected were 0.31 and 1.70, 0.44 and 3.00, 0.29 and $0.88,0.50$ and 5.00, 0.80 and 2.40, 0.30 and 4.00, 0.60 and $1.10,0.25$ and $1.70,0.65$ and $2.00,0.35$ and $0.82,0.10$ and 5.40, 0.12 and 4.90, and 0.50 and $1.90 \mathrm{mg} / \mathrm{L}$ as $\mathrm{F}$ for $\mathrm{Al}$ Baha, Al Jouf, Asir, Eastern Province, Hadwood Shamalyah, Hail, Jizan, Makkah Al Mukaramma, Madina Al Munnawara, Najran, Qassim, Riyadh, and Tabouk regions of the Kingdom, respectively.

Only seven well water samples in the three regions of the Kingdom were found to exceed the fluoride maximum contaminant limits set by USEPA. Out of these seven wells, four were located in Qassim, two in the Riyadh region, and one in the Eastern Province area. In the Qassim region $3.7 \%$ of the well water samples exceeded the USEPA limits whereas in Riyadh region $1 \%$ well water samples exceeded the prescribed limits. In the Eastern Province $0.5 \%$ well water samples exceeded the USEPA limits. Considering secondary USD EPA contaminant limits 6, 12, 10, 9, 11, and 12 well water samples from Al Jouf, Eastern Province, Hadwood Shamalyah, Hail, Qassim, and Riyadh regions, respectively exceeded the $2.0 \mathrm{mg} / \mathrm{L}$ fluoride limit. The land around these wells is mainly used for agricultural and residential purposes. However, some of the wells were located in the desert area. It can be said that source of fluoride is from agriculture practices, geological sources, and human activities.

Higher content of fluoride in drinking water can cause severe health problems, particularly in arid and semi-arid regions. This could be due to the prevalent climatic conditions which necessitate people to drink water in quantities higher than what people drink in temperate regions. To investigate the relationship between fluoride levels in well drinking water, the severity of dental fluorosis and dental caries in the Hail region of Saudi Arabia, 2,355 rural children aged 12-15 years were examined. Over $90 \%$ of the children had fluorosed teeth and Chi square tests showed a strong association $(P<0.001)$ between fluoride level $(0.5-2.8 \mathrm{ppm})$ in well drinking water and severity of dental fluorosis (Akpata et al. 1997).

In setting national standards or local guidelines for fluoride or in evaluating the possible health consequences of exposure to fluoride, it is essential to consider the average daily intake of water by the population of interest and the intake of fluoride from other sources (e.g. from food and air). Where the intakes are likely to approach, or be greater than, $6 \mathrm{mg} / \mathrm{day}$, it would be appropriate to consider setting a standard or local guideline at a concentration lower than $1.5 \mathrm{mg} / \mathrm{L}$ (WHO 2011). 
Table 2 Concentration of fluoride in different regions of the kingdom of Saudi Arabia

\begin{tabular}{|c|c|c|c|c|c|c|c|c|c|c|}
\hline \multirow[t]{3}{*}{ Region } & \multicolumn{3}{|c|}{ Fluoride concentration $\mathrm{mg} / \mathrm{L}$} & \multirow{3}{*}{$\begin{array}{l}\text { Standard } \\
\text { deviation }\end{array}$} & \multirow{2}{*}{\multicolumn{3}{|c|}{$\begin{array}{l}\text { No. of samples exceeding the } \\
\text { maximum contaminant limits }\end{array}$}} & \multirow{2}{*}{\multicolumn{3}{|c|}{$\begin{array}{l}\text { Percentage of wells exceeding the } \\
\text { limits }\end{array}$}} \\
\hline & \multirow{2}{*}{ Minimum } & \multirow{2}{*}{ Maximum } & \multirow{2}{*}{ Average } & & & & & & & \\
\hline & & & & & $\begin{array}{l}\text { USEPA } \\
\text { MCL }\end{array}$ & $\begin{array}{l}\text { USEPA } \\
\text { SMCL }\end{array}$ & WHO & $\begin{array}{l}\text { USEPA } \\
\text { MCL }\end{array}$ & $\begin{array}{l}\text { USEPA } \\
\text { SMCL }\end{array}$ & WHO \\
\hline Al Baha & 0.31 & 1.70 & 0.60 & 0.22 & 0.00 & 0.00 & 2 & 0.00 & 0.00 & 3 \\
\hline Al Jouf & 0.44 & 3.00 & 1.16 & 0.66 & 0.00 & 6 & 7 & 0.00 & 17.6 & 20.5 \\
\hline Asir & 0.29 & 0.88 & 0.66 & 0.12 & 0.00 & 0.00 & 0.00 & 0.0 & 0.00 & 0.00 \\
\hline Eastern province & 0.50 & 5.00 & 1.33 & 0.44 & 1 & 12 & 26 & 0.5 & 6 & 13 \\
\hline Hadwed Shamalyah & 0.80 & 2.40 & 1.80 & 0.35 & 0.00 & 10 & 35 & 0.00 & 24.4 & 85 \\
\hline Hail & 0.30 & 4.00 & 1.37 & 1.02 & 0.00 & 9 & 12 & 0.00 & 22.5 & 30 \\
\hline Jizan & 0.60 & 1.10 & 0.73 & 0.08 & 0.00 & 0.00 & 0.0 & 0.00 & 0.00 & 0.00 \\
\hline $\begin{array}{l}\text { Makkah Al- } \\
\text { Mukaramma }\end{array}$ & 0.25 & 1.70 & 0.74 & 0.18 & 0.00 & 0.00 & 1 & 0.00 & 0.00 & 1.2 \\
\hline $\begin{array}{l}\text { Madina Al- } \\
\text { Munnawara }\end{array}$ & 0.65 & 2.00 & 0.90 & 0.28 & 0.00 & 0.00 & 4 & 0.00 & 0.00 & 5.6 \\
\hline Najran & 0.35 & 0.82 & 0.64 & 0.11 & 0.00 & 0.00 & 0.00 & 0.00 & 0.00 & 0.0 \\
\hline Qassim & 0.10 & 5.40 & 1.11 & 1.01 & 4 & 11 & 23 & 3.7 & 10.2 & 21 \\
\hline Riyadh & 0.12 & 4.90 & 1.01 & 0.69 & 2 & 12 & 36 & 1 & 6 & 18 \\
\hline Tabouk & 0.50 & 1.90 & 0.81 & 0.39 & 0.00 & 0 & 2 & 0.00 & 0.00 & 6.5 \\
\hline
\end{tabular}

USEPA primary maximum contaminant limits: $4.0 \mathrm{mg} / \mathrm{L}$

USEPA secondary maximum contaminants limits (SMCL) for fluoride: $2.0 \mathrm{mg} / \mathrm{L}$

WHO guideline limits: $1.5 \mathrm{mg} / \mathrm{L}$

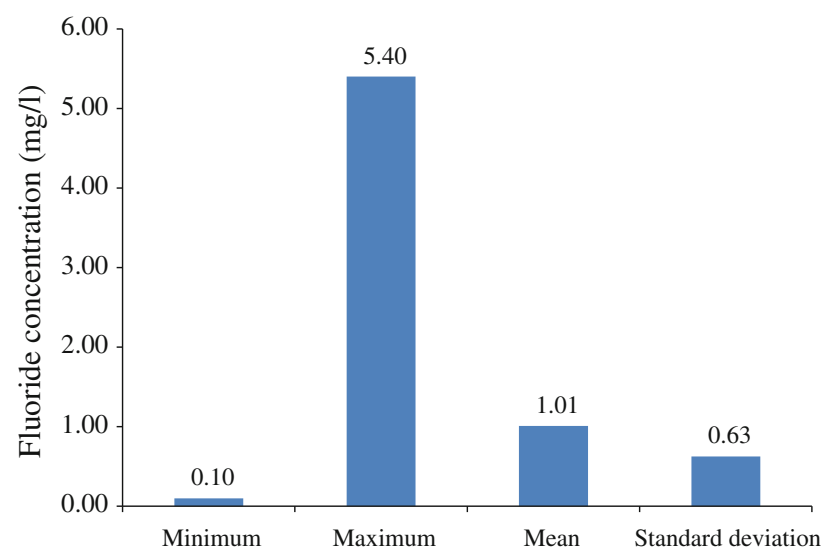

Fig. 2 Minimum, maximum levels, mean and standard deviation of fluoride in Saudi Arabia

\section{Correlation of fluoride concentration with depth of the sampled wells}

Fluoride concentrations were plotted against the depths of the sampled wells. Observed fluoride concentrations versus well depths in different regions of the Kingdom are shown in Fig. 3. It is known that depths of the deep wells can go up to thousands of meters. The figure shows that comparatively higher levels of fluoride were found in relatively less deep wells (1,000 meters). These relatively higher fluoride concentrations may be attributed to the geological factors as well to the contamination from the external sources.

\section{Correlation of fluoride concentration with other cationic and anionic elements}

The correlation of determined fluoride concentrations in the well water samples collected from different locations in the kingdom with other major anions and cations has been presented in Table 3. The software SPSS was used to calculate the correlation between fluoride and other major cations and anions. The highest correlation was found with the parameters calcium (0.62) and sulphate (0.62) followed by sodium (0.54) and magnesium (0.52). The fluoride content was least correlated with the parameter potassium (0.26).

\section{Conclusions and recommendations}

1. Well waters were collected in 13 regions of the Kingdom of Saudi Arabia to evaluate the fluoride concentrations. In all 1,060 wells were sampled.

2. The results indicated that fluoride levels exceeded the maximum allowed limits in considerable number of wells. 
Fig. 3 Correlation of fluoride concentrations with well depths

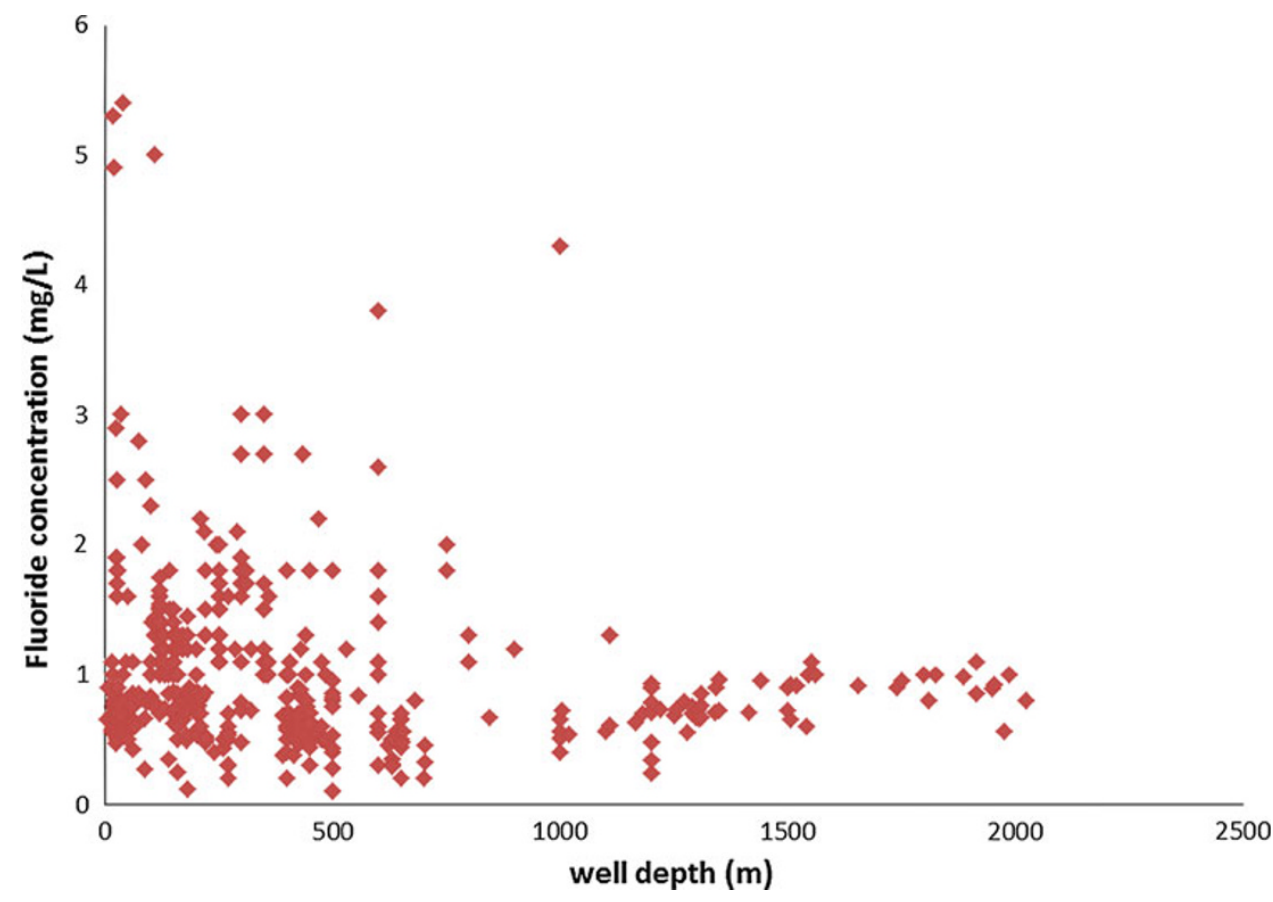

Table 3 Correlation of Fluoride with major cations and anions

\begin{tabular}{ll}
\hline Parameters & Correlation factor \\
\hline Calcium $(\mathrm{Ca})$ & 0.62 \\
Magnesium $(\mathrm{Mg})$ & 0.52 \\
Sodium $(\mathrm{Na})$ & 0.54 \\
Potassium $(\mathrm{K})$ & 0.26 \\
Chloride $(\mathrm{Cl})$ & 0.50 \\
Nitrate $\left(\mathrm{NO}_{3}\right)$ & 0.35 \\
Sulphate $\left(\mathrm{SO}_{4}\right)$ & 0.62
\end{tabular}

3. The maximum percentage of wells exceeding the US EPA maximum contaminant limit of $4.0 \mathrm{mg} / \mathrm{L}$ fluoride limits was in Qassim (3.7\%).

4. The maximum percentage of wells exceeding the secondary US EPA maximum contaminant limit of $2.0 \mathrm{mg} / \mathrm{L}$ fluoride was in the Hail region $(22.5 \%)$.

5. The maximum percentage of wells exceeding the WHO guide line limit of $1.5 \mathrm{mg} / \mathrm{L}$ fluoride was in the Hadwad Shamalyah $(85 \%)$.

6. It is recommended to control the possible sources of groundwater contamination by enforcing drinking water standards and monitoring agricultural activities and speedup completion of sewage system.

7. It is also recommended to treat water in areas where fluoride levels have exceeded the prescribed limits. In addition, measures are needed to be taken to close down wells which contain very high fluoride levels.
Acknowledgments This research was financially supported by King Abdulaziz City for Science and Technology under the Project Grant ARP 15-15.

Open Access This article is distributed under the terms of the Creative Commons Attribution License which permits any use, distribution, and reproduction in any medium, provided the original author(s) and the source are credited.

\section{References}

Agarwal V, Vaish AK, Vaish P (1997) Ground water quality: focus on fluoride and fluorosis in Rajasthan. Curr Sci 73(9):743-746

Akpata ES, Fakiha Z, Khan N (1997) Dental fluorosis in 12-15-yearold rural children exposed to fluorides from well drinking water in the Hail region of Saudi Arabia. Commun Dent Oral Epidemiol 25(4):324-327

Alarcon-Herrera MT et al (2001) Well water fluoride, dental fluorosis, bone fractures in the guadiana valley of Mexico. Fluoride 34(2):139-149

Apambire WB, Boyle DR, Michael FA (1998) Geochemistry, genesis and health implications of fluoriferous groundwater in the upper regions of Ghana. http://www.waterquality.crc.org.au/hsarch/ HS9m.htm. Accessed 17 Dec 2002

APHA (1999) Standard methods for the examination of water and wastewater, 20th edn. Washington, DC

Ayoob S, Gupta AK (2006) Fluoride in drinking water: a review on the status and stress effects. Crit Rev Environ Sci Technol 36:433-487

Breiter K, Kronz A (2004) Phosphorus-rich topaz from fractionated granites (Podlesí, Czech Republic). Mineral Petrol 81:235-247

Breiter K, Förster H, Škoda R (2006) Extreme P-, Bi-, Nb-, U-, and F-rich zircon from fractionated perphosphorous granites: the peraluminous Podlesí granite system, Czech Republic. Lithos $88: 15-34$ 
Chae G, Yun S, Mayer B, Kim K, Kim S, Kwon J, Kim K, Koh Y (2007) Fluorine geochemistry in bedrock groundwater of South Korea. Sci Total Environ 385:272-283

Chapusa FWP, Harrison DR (1975) The Geology of the NkhotakotaBenga Area. Bulletin No. 32 (p. 31-32). Government Printer, Zomba, Malawi

Falvey DA (1999) Groundwater geochemistry. Earthwise (British Geological Survey Magazine) Issue no. 13

Farges F (1996) Does Zr-F "complexation" occur in magmas. Chem Geol 127:253-268

Harrison PTC (2005) Fluoride in water: a UK perspective. J Fluor Chem 126:1448-1456

Hurtado R, Torresdey G, Tiemann KJ (2000) Fluoride occurrence in tap water at Los Altos de Jalisco in the Central Mexico region. http://www.engg.ksu.edu/HSRC/00Proceed/gardeatorredey1.pdf Accessed 20 Oct 2002

Jacks G, Bhattacharya P, Chaudhary V, Singh KP (2005) Controls on the genesis of some high-fluoride groundwaters in India. Appl Geochem 20:221-228

Keppler H (1993) Influence of fluorine on the enrichment of high field strength trace elements in granitic rocks. Contrib Miner Petrol 114:479-488

Kim K, Jeong GY (2005) Factors influencing natural occurrence of fluoride-rich groundwaters: a case study in the southeastern part of the Korean Peninsula. Chemosphere 58:1399-1408

Lennon MA, Whelton H, Mullane DO, Ekstrand J (2004) Rolling revision of the WHO guidelines for drinking-water quality: fluoride. WorldHealthOrganization, pp. 1-12

Lukkari S, Holtz F (2007) Phase relations of a F-enriched peraluminous granite: an experimental study of the Kymi topaz granite stock, southern Finland. Contrib Miner Petrol 153:273-288

Mgalela R (1997) Some aspects of saline groundwaters in Gokwe District. Annals of the Zimbabwe Geological Survey, Harare Zimbabwe

Ministry of Health and Population (MOH) (1996). National Oral Health Plan. Lilongwe, Malawi
Mjengera H, Mkongo G (2002) Appropriate technology for use in fluoritic areas in Tanzania, 3rd Waternet/WARFSA Symposium on water demand management for sustainable use of water resources, University of Dar Es Salaam

Qinghai G, Yanxin W, Teng M, Rui M (2007) Geochemical processes controlling the elevated fluoride concentrations in groundwaters of the Taiyuan Basin Northern China. J Geochem Explor 93(1): $1-12$

Reddy DV, Nagabhushanam P, Sukhija BS, Reddy AGS, Smedley PL (2010) Fluoride dynamics in the granitic aquifer of the Wailapally watershed, Nalgonda district, India. Chem Geol 269:278-289

Sibale FK, Chidothi C, Tsakala E (1998) Oral health status among the 12 and 15 year old school pupils in Machinga District, Malawi

Tekle-Haimanot R, Melaku Z, Kloos H, Reimann C, Fantaye W, Zerihun L et al (2006) The geographic distribution of fluoride in surface and groundwater in Ethiopia with an emphasis on the Rift Valley. Sci Total Environ 36701:182-190

Totsche KU, Wilcke W, Korbus M, Kobza J, Zech W (2000) Evaluation of fluoride induced metal mobilization in soil columns. J Environ Qual 29:454-459

US Environmental Protection Agency (USEPA) (2012) http://water. epa.gov/drink/contaminants/index.cfm

Wodeyar BK, Sreenivasan G (1996) Occurrence of fluoride in the groundwater and its impact in Peddavankahalla Basin, Bellary District Kamataka—a preliminary study. Curr Sci 70:71-74

World Health Organization (2011) Revision of the WHO guidelines for drinking water quality. World Health Organization, Geneva

Xiong X, Liu J, He W, Xia T, He P, Chen X, Yang K, Wang A (2007) Dose-effect relationship between drinking water fluoride levels and damage to liver and kidney functions in children. Environ Res 103:112-116

World Health Organisation (1994) Fluorides and oral health, (Technical Report Series No. 846). WHO, Geneva

Zhu L, Zhang HH, Xia B, Xu DR (2007) Total fluoride in Guangdong soil profiles, China: spatial distribution and vertical variation. Environ Int 33:302-308 